This is an electronic reprint of the original article. This reprint may differ from the original in pagination and typographic detail.

Please cite the original version: Martikainen, S. \& Palo, L. (2018). Turvallisuutta vanhojen ihmisten kotihoitoon yhteiskehittämisen keinoin. Gerontologia, 32(3), 209-214.

doi: $10.23989 /$ gerontologia.75362

URL: https://doi.org/10.23989/gerontologia.75362 


\title{
Turvallisuutta vanhojen ihmisten kotihoitoon yhteiskehittämisen keinoin
}

\author{
Soili Martikainen \& Lilja Palo
}

Vantaan kaupungin ikääntyneiden avopalvelut ja Laurea-ammattikorkeakoulu tarttuivat kotihoidon turvallisuuden haasteisiin yhteiskehittämisen keinoin. Laurean opiskelijat järjestivät kotihoidon henkilökunnalle kaksi saman sisältöistä turvallisuusiltapäivää, joiden työpajoissa kehitettiin sekä kotona asuvien vanhusten että heidän kodeissaan työskentelevän kotihoidon henkilöstön turvallisuutta. Yhteiskehittämisessä kytkettiin yhteen kotihoidon asiantuntijoiden ammatillinen osaaminen sekä sote-alan opiskelijoiden tuore turvallisuus- ja riskienhallintaosaaminen.

Ikäihmisten määrä kasvaa - onnettomuudet vaarantavat kotona asumisen

Elinajanodote on kasvanut Suomessa nälkävuosien 1867-1868 jälkeen ja eliniän piteneminen jatkuu todennäköisesti myös tulevaisuudessa (Elinajanodote 2016). Ennusteen mukaan yli 65-vuotiaiden määrä kasvaa Suomessa 19,9 prosentista 26 prosenttiin vuoteen 2030 mennessä. Vuonna 2060 yli 65-vuotiaiden osuus on jo 29 prosenttia väestöstä. (Tilastokeskus 2015.) Kun väestö vanhenee ja ikääntyneiden laitoshoito vähenee, kasvaa kotihoidon tarve. Säännöllisen kotihoidon asiakkaista suuri joukko, 77 prosenttia, onkin 75 vuotta täyttäneitä (THL 2018a).

Ikäihmiset tarvitsevat toimintakykynsä heikentyessä terveyttä ja hyvinvointia edistäviä palveluja voidakseen elää kotona mahdol- lisimman pitkään. Eliniän pitenemisen myötä ikääntyneille tyypillisten sairauksien märä kasvaa ja samalla vaikeasti hoidettavien ja monisairaiden määrä kasvaa. Erityistä tukea tarvitsevia ikääntyneitä henkilöitä ovat muun muassa kotona asuvat muistisairaat, korkean kaatumisriskin asiakkaat, tiuhaan päivystyspoliklinikalla asioivat, mielenterveysasiakkaat sekä päihteitä käyttävät henkilöt (THL 2018b). Palvelutarpeiden arviointi ja palvelutarpeisiin vastaaminen vaativat monipuolista osaamista. Kotihoidon tehtäväkenttä laajenee ja samalla ammatillisen osaamisen vaatimukset kasvavat. (THL 2017.)

Kotihoidon turvallisuus on tärkeä aihe, sillä muistamattomien ja toimintakyvyltään rajoittuneiden kotona asuvien henkilöiden märän noustessa kasvaa myös riski erilaisten onnettomuuksien lisääntymiseen. Tilastojen mukaan kotitapaturmat ovat paljon yleisempiä kuin muun tyyppiset tapaturmat yli 75-vuotiailla henkilöillä. Tyypillisimmät kotitapaturmat ovat kaatumisia, kompastumisia, liukastumisia ja putoamisia alle yhden metrin korkeudelta. Vammat ovat yleensä mustelmia, ruhjeita, haavoja, nyrjähdyksiä, venähdyksiä, sijoiltaanmenoja ja palovammoja. (Haikonen ym. 2017, 15-16; 37.) Ikääntyminen altistaa kaatumiselle ja jo pienetkin kaatumisesta aiheutuneet vammat vaativat ikäihmisillä usein käynnin terveydenhuollon vastaanotolla (THL 2018c). Tilastokeskuksen mukaan kaatumis- ja putoamiskuolemia tapahtui erityisesti iäkkäille 
ihmisille: kolme neljästä kaatumistapaturmissa kuolleista oli yli 75-vuotias. (Tilastokeskus 2017.)

\section{Turvallisuusiltapäivät yhteiskehittämisen keinona}

Ammattikorkeakoulun tehtävänä on antaa tuleville ammattilaisille valmiuksia toimia ympäröivän maailman muutoksen edellyttämällä tavalla ja siksi vahva kytkentä työelämän asiantuntijoihin on tärkeässä asemassa. Ympäröivän maailman ja väestörakenteen muuttumisen myötä hoitotyö on voimakkaiden muutosten äärellä, jonka vuoksi Laurea-ammattikorkeakoulussa on lisätty kokonaisvaltaisen turvallisuuden ja riskienhallinnan opetusta. (Palo 2016, 12.) Laurea tarjoaa sairaanhoitajaja sosionomiopiskelijoiden täydentävissä opinnoissa kokonaisturvallisuuden moduulin, jonka avulla uusilla, valmistuvilla sairaanhoitajilla ja sosionomeilla on entistä enemmän osaamista kokonaisturvallisuudesta ja riskienhallinnasta. Jokaisen terveydenhuollon organisaation toimintaan liittyy riskejä (Martikainen 2016, 32). Arjen työssä tarvitaan hoitajia, jotka kykenevät hahmottamaan työpaikan turvallisuutta kokonaisvaltaisesti, tunnistavat vaaroja, osaavat tehdä riskienarviointia, kuten myös suunnitella ja toteuttaa tarvittavia korjaavia toimia.

Kotihoidon henkilöstön tärkeä osaamisalue on kokonaisturvallisuus- ja riskienhallintaosaaminen. Tapaturmien ennaltaehkäisy on erityisen tärkeää, sillä tapaturmien seuraukset ovat iän lisääntyessä vakavampia. Tapaturma iäkkäänä voi johtaa siihen, että pärjääminen kotona omin voimin heikkenee. (www.kotitapaturma.fi/turvallisia-vuosia.) Hyvään turvallisuuskulttuuriin kuuluu, että työntekijä tunnistaa turvallisuuteen vaikuttavat riskit työpaikallaan, joka kotihoidon tapauksessa on asiakkaan koti. Oman työpaikan riskien arviointi ja tarvittaessa riskien pienentäminen vaikuttavat merkittävästi työn turvallisuuteen. Tällaisia asiakkaan kotona esiintyviä riskejä ovat muun muassa onnettomuuksien ja tapaturmien mahdolli- suutta lisäävät tekijät. Helppo keino tunnistaa riskejä on dokumentoida kaikki "läheltä piti" -tilanteet.

Vantaan kaupungin vanhusten avopalvelut ja Laurea-ammattikorkeakoulu päättivät yhdessä tarttua vanhusten kotihoidon turvallisuuteen yhteiskehittämisen keinoin syksyllä 2017. Yhteiskehittämisellä tarkoitetaan tavoitteellista yhteistyötä ja kokemusten mukaan se soveltuu hyvin palvelujen, tilaratkaisujen ja toimintatapojen kehittämiseen. Ikääntyneiden avopalvelujen esimiehet kertoivat Laurean sote-alan opiskelijoille ja opettajille, mitä turvallisuuteen liittyviä haasteita kotihoidon henkilöstö on havainnut. Kotihoidon esimiehiltä saadun pohjatiedon perusteella opiskelijat opettajien ohjaamina tekivät ehdotuksen, miten turvallisuutta voitaisiin kehittää. Kotihoidon henkilöstölle päätettiin järjestää kaksi saman sisältöistä turvallisuusiltapäivää, jotta mahdollisimman monella olisi mahdollisuus osallistua. Tavoitteena oli kehittää kotihoidon turvallisuutta sekä asiakkaan että kotihoidon työntekijöiden näkökulmasta erilaisia riskiperusteisia ja tutkittuun tietoon pohjautuvia menetelmiä käyttäen. Turvallisuusiltapäivässä yhdistettiin Vantaan kaupungin vanhusten avopalvelujen työntekijöiden ammatillinen osaaminen sekä sote-alan opiskelijoiden tuore turvallisuus- ja riskienhallintaosaaminen.

Yhteensä 90 vanhusten avopalvelujen esimiestä ja työntekijää osallistui turvallisuusiltapäivien työpajoihin loppuvuonna 2017. Turvallisuusiltapäivät muodostuivat neljästä eri osallistavasta työpajasta, jotka toteutettiin neljästä eri aiheesta: 1) turvallisesti kotona, 2) haasteellisen käyttäytymisen ennaltaehkäisy ja hallinta MAPA $^{\circledR}$ (Management of Actual or Potential Aggression) -koulutuksen keinoin, 3) aggressiivisen asiakkaan kohtaaminen puhelimessa sekä 4) ISBAR (Identify - Situation - Background - Assessment - Recommendation) -raportointijärjestelmä. Kunkin työpajan kesto oli 30 minuuttia ja osallistujat kiersivät pienryhminä kaikki työpajat. Laurean opiskelijat käynnistivät työpajat alustuksilla, jonka jälkeen työ- 
pajat etenivät keskustellen, tietoa rakentaen ja kokemuksia vaihtaen. Kotihoidon työntekijät tekivät yhdessä opiskelijoiden ohjaamina työpajojen tehtäviä, kuvasivat työpajoissa käytännön esimerkkitilanteita sekä kehittivät niiden kautta käytännössä toimivia, turvallisuutta parantavia ratkaisuja. Opiskelijat dokumentoivat työpajoissa tuotetun tiedon raporteiksi ikääntyneiden avopalvelujen turvallisuustyön jatkokehittämistä varten.

\section{Turvallisesti kotona}

Turvallisesti kotona -työpajassa tehtävänä oli tunnistaa turvallisuusriskit kodin eri huoneissa ja samalla myös kirjata muistiin toimenpiteitä, joilla riskit voidaan pienentää tai poistaa. Tarkasteltavia tiloja olivat eteinen, makuuhuone, olohuone, keittiö ja pesutilat. Osallistujat istuivat vastakkain pitkässä pöydässä. Osallistujien kesken pöydässä kierrätettiin eri tiloja varten laadittuja lomakkeita, johon osallistujat täydensivät omia riskeihin liittyviä havaintojaan sekä tekivät myös ehdotuksia korjaaviksi toimiksi. Ajatuksien ja ideoiden virittämistä varten pöydällä oli Turvallisia vuosia -esite, tarkastuslista tapaturmien ehkäisemiseksi sekä Turvallisesti kotona -juliste. Lisäksi läheisellä pöydällä oli oheismateriaalina alkusammutusohjeet ja palohälytin osiin purettuna. Osallistujat saivat työpajan jälkeen mukaansa materiaalia kodin turvallisuudesta.

Matot ovat useimmiten syynä kotona kaatumiseen. Maton reunaan voi kompastua tai matto voi aiheuttaa liukastumisen. Tehokkain riskinhallintakeino on poistaa kaikki matot lattioilta. On kuitenkin kunnioitettava asiakkaan itsemääräämisoikeutta, joten mattoja ei voida poistaa kodista ilman asiakkaan suostumusta. Kaatumisriskiä voidaan pienentää myös asettamalla liukuesteet maton alle. Vaikka kaatumisriski olisikin suuri, voi liukuesteiden käyttäminen olla ikääntyneelle henkilölle mieluisampi valinta.

Merkittäväksi riskitekijäksi potilaiden kotona tunnistettiin myös huoneiden ahtaus ja ta- varoiden paljous. Ahtaus vaikeuttaa liikkumista ja liiallisen tavaramäärän vuoksi tapahtuu kompastumisia ja tavaroiden putoamisia. Ahtauden vuoksi tavaroita sijoitetaan myös turvattomiin ja erikoisiin paikkoihin, kuten tavaroiden laskeminen lieden päälle sekä sanomalehtien säilyttäminen uunissa. Eritysesti keittiössä ikäihmisen putoamisriskiä lisää esineiden sijoittelu liian korkealle ja vaikeasti tavoitettaviin paikkoihin. Korjaaviksi toimenpiteiksi ehdotettiin tavaroiden määrän karsimista sekä niiden sijoittamista turvalliseen, käytännölliseen paikkaan.

Työpajan osallistujat totesivat, että kodin turvallisuudesta puhuminen asiakkaan kanssa on tärkeää. Lisäksi korostettiin, että ikääntyneen henkilön hoito kotona ja kodin turvallisuuden parantaminen tapahtuvat kotihoidon asiakkaan ehdoilla hänen itsemääräämisoikeuttaan kunnioittaen. Myös tarkistuslistan edut tulivat vahvasti esille. Esimerkiksi ensimmäisellä kotikäynnillä hoitohenkilökunnan on helppo kartoittaa tarkistuslistan ja turvakävelyn avulla kodin riskit sekä tehdä ehdotuksia riskien pienentämiseksi. Työpajassa tunnistettiin henkilöstön lisäkoulutuksen tarve muun muassa paloturvallisuudesta, työturvallisuudesta sekä asiakkaan itsemääräämisoikeuden tukemisesta, kuten myös itsemääräämisoikeudesta aiheutuvista erityistilanteista.

Haasteellisen käyttäytymisen ennaltaehkäisy ja hallinta

Management of Actual or Potential Aggression -koulutusohjelma (MAPA ${ }^{\circledR}$ ) on kansainvälinen toimintamalli, joka on tuotu Suomeen IsoBritanniasta 2000-luvun alussa. Vuodesta 2005 alkaen Laurea on tarjonnut Positive Options (UK) kanssa Mapa ${ }^{\circledR}$-kouluttajien koulutusta. MAPA ${ }^{\circledR}$ opetetaan työkirjamallin avulla ja MAPAssa on mahdollista suorittaa eritasoisia ja -laajuisia opintojaksoja. Vuonna 2015 Suomen mapakeskus aloitti toimintansa Laurean Hyvinkään kampuksella Crisis Prevention Institute (CPI) kanssa solmitun 
sopimuksen pohjalta. MAPAssa ennakoivat menetelmät, turvallisuus ja kivuttomuus ovat keskeisessä roolissa. Kaikki käytettävät menetelmät on arvioitu ja hyväksytty The British Institute of Learning Disabilities -instituutin laatiman kriteeristön mukaisesti, jotta varmistetaan käytettävien tekniikoiden turvallisuus niin potilaan kuin hoitajankin näkökulmasta. (http://suomenmapakeskus.fi/.)

MAPAn mukaan on tärkeää ymmärtää kriisin etenemisen vaiheet sekä se, mistä asioista potilaan käyttäytymisessä voi päätellä kriisin vaiheen. Hoitajan tehtävänä on pyrkiä ehkäisemään kriisin eteneminen riskikäyttäytymisen tasolle ja toisaalta osata toimia turvallisesti akuuteissa kriisitilanteissa. Kriisin jälkeen on tärkeää käsitellä kriisitilanne sekä hoitajien että potilaan kanssa ja solmia tasa-arvoinen yhteistyösuhde. Sekä potilas että hoitaja voivat oppia ja muuttaa omaa käyttäytymistään jälkipuinnin avulla. (Suomen mapa ${ }^{\circledR}$ keskus 2015.)

MAPA-työpajassa osallistujat keskustelivat kriisin ennaltaehkäisystä ja liennyttämisestä ennen kuin potilaan käyttäytyminen muuttuu riskikäyttäytymiseksi. Tämän jälkeen tehtiin käytännön harjoituksia. MAPAn tavoitteena on ohjata henkilöstöä ehkäisemään haasteellista käytöstä huomioiden yksilölliset tarpeet sekä toiminta lainsäädännön, ammatillisten ohjeiden ja eettisten periaatteiden mukaan. Työpajan toiminnallisuus koettiin innostavaksi ja osallistujat tekivät ohjaajien johdolla aktiivisesti irrottautumisharjoituksia.

\section{Potilasturvallisuutta tiedonsiirtoa kehittämällä}

Sairaanhoitajaliiton mukaan noin 70 prosenttia terveydenhuollon haittatapahtumista aiheutuu kommunikaation ongelmista, kuten tiedonkulun katkeamisesta ja väärinymmärryksistä. Kirjallisen kommunikaation merkitys korostuu terveydenhuollon monimutkaisessa ympäristössä. Yhdysvaltojen merivoimissa kehitettiin 1990-luvulla SBAR-menetelmä, jonka käyttö laajeni nopeasti myös terveyden- huoltoon. ISBAR-menetelmä on sen sovellus suomalaiseen terveydenhuoltoon. (Suomen Potilasturvallisuusyhdistys 2014.) Suomen Potilasturvallisuusyhdistys yhdessä Terveyden ja hyvinvoinnin laitoksen ja Sairaanhoitajaliiton kanssa ovat sekä kehittäneet että levittäneet ISBAR-menetelmää Suomessa. ISBAR-lyhenne tulee sanoista Identify (tunnista), Situation (tilanne), Background (tausta), Assessment (nykytilanne) ja Recommendation (toimintaehdotus). ISBARissa käytetään sekä kiireellisiin ja kiireettömiin tapauksiin suunniteltuja tarkistuslistoja, joiden tavoitteena on parantaa terveydenhuollon raportointia ja tätä kautta potilasturvallisuutta. Menetelmä kannustaa kriittiseen ajatteluun sekä rohkaisee tekemään kehittämisehdotuksia. (Sairaanhoitajat 2014; Suomen Potilasturvallisuusyhdistys 2014.)

Turvallisuusiltapäivien ISBAR-työpajassa osallistujat harjoittelivat ISBAR-tarkistuslistan käyttöä suullisen raportoinnin työkaluna. Osallistujat työskentelivät kahdessa ryhmässä käyttäen yhteistoiminnallista Learning cafe - menetelmää, jossa tarkoituksena on jatkaa ideoita sekä tarkastella käsiteltävää aihetta mahdollisimman monesta erilaisesta näkökulmasta. Työpajan aluksi näytettiin video ISBARmenetelmästä. Tämän jälkeen molempiin pöytäryhmiin annettiin omat tapauskuvaukset, joista ensimmäinen käsitteli kiireetöntä ISBARia ja toinen työssä havaittuja haasteita asiakasraportoinnissa. Sovitun ajan jälkeen ryhmät vaihtoivat tapauskuvauksia keskenään. Osalle Vantaan kaupungin työntekijöistä ISBAR oli entuudestaan tuttu menetelmä, mutta joukossa oli myös sellaisia henkilöitä, joille tämä oli täysin uutta.

Osallistujat olivat varsin yksimielisiä siitä, että ISBAR-menetelmä selkeyttää tiedonsiirtoa. Sen avulla raportointi etenee sovitulla "kaavalla" ja näin työntekijä muistaa helpommin tuoda esiin kaikki oleelliset asiat. Kun monta vanhusten avopalvelujen asiantuntijaa oli pohtimassa tiedonkulun ongelmien ratkaisuvaihtoehtoja samassa työpajassa, niin syntyi myös hyviä ideoita. Työpajan perusteella yksi osal- 
listujista teki konkreettisen kehitysehdotuksen: kotihoidon asiakaskansioihin tarvitaan potilaskohtainen ISBAR-sivu raportointia varten.

\section{Kuuntele ja keskustele}

Sosiaali- ja terveydenalan ammattilaiset kohtaavat yhä useammin väkivaltaisesti tai aggressiivisesti käyttäytyviä asiakkaita ja potilaita. Vuorovaikutustaidoista ja asiakkaan tilanteen ymmärtämisestä on kysymys myös puhelintyössä. Usein syynä aggressiiviseen käyttäytymiseen on monen tapahtuman tai tilanteen kasaantuminen, jolloin vihaisen purkauksen voi käynnistää pienikin asia. Työntekijät, joilla on hyvä ammatillinen itseluottamus, kestävät muita paremmin tällaisia stressitilanteita. $\mathrm{He}$ myös kykenevät käsittelemään muita paremmin asiallisen kritiikin sekä ohittamaan aiheettoman ja asiattoman kritiikin. (Rantaeskola, Hyyti, Kauppila \& Koskelainen 2015, 8-9.)

Puhelimessa on tärkeä muistaa sanaton viestintä, jonka välitämme asiakkaalle. Annamme asiakkaalle ensivaikutelman itsestämme, kun vastaamme puheluun. Sopiva äänenpaino, selkeä esittely, puheen rauhallisuus ja kiireetön vaikutelma ovat hyviä lähtökohtia. Toisinaan puhelimessa on vaikea kielellisten tai muiden syiden vuoksi ymmärtää, mitä asiakas sanoo. Tärkeää on toistaa ja varmistaa kuulemansa, jotta asiakas tietää tulleensa ymmärretyksi. (Laine, Ruishalme, Sivén \& Välimäki 2012.)

Omien voimavarojen tunnistaminen on merkityksellinen lähtökohta. Jos hoitaja lähtee puhelun aikana mukaan potilaan aggressiivisuuteen, voi hän huomaamattaan ruokkia aggressiivisuutta. Haasteellisten puhelujen jälkeen on hyvä pohtia omaa ja potilaan tai omaisen puhelukäyttäytymistä sekä miettiä, mitä olisi voinut tehdä toisin. Jos tilanteessa on mukana muita työntekijöitä, voi heiltä saada kehittämisehdotuksia. Ammattitaitoinen työntekijä osaa käyttäytyä niin, ettei arvovaltakiistoja synny. Hän tietää, mitä omaan työnkuvaan kuuluu, sekä mitkä ovat omat mah- dollisuudet ja velvollisuudet toimia tilanteessa. (Rantaeskola ym. 2015, 50-51.) Tarvittaessa työntekijä voi neuvotella esimiehensä kanssa mahdollisuudesta saada lisäkoulutusta haastavien tilanteiden hoitamiseen.

Aggressiivinen asiakas puhelimessa -työpaja toteutettiin roolipelinä, jossa puhelimessa keskustelivat vihainen omainen ja kotihoidon sairaanhoitaja. Opiskelijat heittäytyivät rooleihin ja kotihoidon työntekijät seurasivat keskustelua. Kun puhelu oli ohi, kotihoidon työntekijät kommentoivat keskustelua sekä antoivat ohjaavaa palautetta. Yksi opiskelijoista toimi juontajana ja toinen kirjasi muistiin kotihoidon työntekijöiden antamat kommentit. Roolipeli tehtiin uudestaan kuulijoilta saatuja ohjeita noudattaen. Saadun palautteen mukana kaikki oppivat tilanteesta.

\section{Lopuksi}

Vantaan kaupungin vanhusten avopalvelujen henkilöstön sekä Laurean sote-alan opiskelijoiden yhteistyö kotihoidon turvallisuuden äärellä oli oivallinen keino toteuttaa yhteiskehittämistä. Turvallisuusiltapäivien suunnittelu ja toteutus oli opettavainen ja samalla mieluinen kokemus sekä Laurean opiskelijoille, kuin myös mukana olleille opettajille, lehtori Lilja Palolle ja lehtori Soili Martikaiselle. Yhteiskehittämisessä hyödynnettiin sekä työelämän asiantuntijoiden että opiskelijoiden tietoja, jolloin kaikkien osallistujien osaaminen kasvoi. Sote-alan opiskelijat toivat yhteiskehittämiseen mukaan erilaisia riskiperusteisia ja tutkittuun tietoon pohjautuvia menetelmiä ja saivat työelämän asiantuntijoilta konkreettista tietoa työssä kohdattavista, arjen turvallisuuteen vaikuttavista riskeistä. Samalla opiskelijat saivat kokemusta henkilökunnan turvallisuuskoulutuksen suunnittelusta ja toteutuksesta. Yhteistyöllä pystyttiin kehittämään vanhusten avopalvelujen turvallisuutta sekä vanhusten että työntekijöiden osalta. 


\section{Yhteydenotto:}

Soili Martikainen, TkT, lehtori,

Laurea-ammattikorkeakoulu

Sähköposti: soili.martikainen@laurea.fi

Lilja Palo, THM, lehtori,

Laurea-ammattikorkeakoulu

Sähköposti: 1ilja.palo@laurea.fi

\section{Kirjallisuus}

Haikonen, K., Doupi, P., Honkala, E., Nipuli, S., October, M. \& Lounamaa, A. 2017. Suomalaiset tapaturmien uhrina 2017. Kansallisen uhritutkimuksen tuloksia. Työpaperi 45/2017, Terveyden ja hyvinvoinnin laitos. Haettu osoitteesta 5.9.2018: http://www.julkari.fi/bitstream/handle/10024/135809/URN_ISBN_978-952-302993-4.pdf?sequence=1

Koti- ja vapaa-ajan tapaturmien ehkäisy 2015. Turvallisia vuosia. Tietoa tapaturmien ehkäisemiseksi iäkkäille ja heidän läheisilleen. Haettu 6.9.2018 osoitteesta: https://frantic.s3-eu-west-1.amazonaws.com/kotitapaturma/2015/12/21103729/ Turvallisia_vuosia_2015.pdf

Laine, A., Ruishalme, O., Salervo, P., Sivén, T. \& Välimäki, P. 2012. Opija objaa sosiaali-ja terveysalalla. 9.-10. Painos. Helsinki: Sanoma Pro.

Martikainen, S. 2016. Riskienhallinta ja kokonaisvaltainen turvallisuus osana sairaanhoitajan työtä. Teoksessa Martikainen S. \& Palo L. (toim.) 2016. Sairaanhoitaja hoitotyön turvallisuuden kehittäjänä. Laurea Julkaisut 74., Laurea-ammattikorkeakoulu. s. 32-41. Haettu 3.9.2018 osoitteesta: http://www.theseus.fi/handle/10024/121780

Palo, L. 2016. Safe Nurse - Sairaanhoitaja hoitotyön riskienhallinnan osaajana. Teoksessa Martikainen S. \& Palo L. (toim.) 2016. Sairaanhoitaja hoitotyön turvallisuuden kehittäjänä. Laurea Julkaisut 74., Laurea-ammattikorkeakoulu. s. 12-21. Haettu 3.9.2018 osoitteesta: http:// www.theseus.fi/handle/10024/121780

Rantaeskola, S,. Hyyti, J. Kauppila, J \& Koskelainen, M. 2015. Haastavat asiakastilanteet - väkivalta työssä. Helsinki: Alma Talent.

Sairaanhoitajat 2014. Potilasturvallisuus. Haettu 6.9.2018 osoitteesta: https://sairaanhoitajat.fi/ artikkeli/potilasturvallisuus/
Suomen mapa ${ }^{\circledR}$ keskus 2015. Haasteellisen käyttäytymisen ennaltaehkäisy ja hallinta. Osallistujan työkirja.

Suomen mapa ${ }^{\circledR}$ keskus 2018. Koulutusta haastavien ja aggressiivisten henkilöiden kohtaamiseen. Haettu osoitteesta 4.9.2018: http://suomenmapakeskus.fi/

Suomen Potilasturvallisuusyhdistys 2014. Potilasturvallisuuden työkaluja. Haettu 5.9.2018 osoitteesta: http://77.86.226.93/wordpress/wp-content/uploads/2015/08/akm_Potilasturvallisuuden_tyokalut_2014.pdf

Terveyden ja hyvinvoinnin laitos (THL) 2017. Kotihoidon asiakasmäärä kasvanut, mutta henkilöstön määrä vähentynyt. Haettu osoitteesta 6.9.2018: https://thl.fi/fi/-/kotihoidon-asiakasmaara-kasvanut-mutta-henkiloston-maara-vahentynyt

Terveyden ja hyvinvoinnin laitos (THL) 2018a. Säännöllisen kotihoidon asiakkaat marraskuussa 2017. Haettu 6.9.2018 osoitteesta: https://thl. fi/fi/tilastot-ja-data/tilastot-aiheittain/ikaantyneiden-sosiaalipalvelut/kotihoidon-asiakkaat

Terveyden ja hyvinvoinnin laitos (THL) 2018b. Vanhuspalvelujen tila maakunnissa. Haettu 6.9.2018 osoitteesta: https://thl.fi/fi/web/ikaantyminen/ toimivat-vanhuspalvelut/vanhuspalvelujen-tila/ vanhuspalvelujen-tila-maakunnissa\#erityisosaaminen

Terveyden ja hyvinvoinnin laitos 2018c. Ikääntyneiden tapaturmat. 2018. Haettu osoitteesta 5.9.2018: https://thl.fi/fi/web/hyvinvoinnin-ja- terveydenedistamisen-johtaminen/turvallisuuden-edistaminen/tapaturmien-ehkaisy/ikaantyneiden-tapaturmat

Tilastokeskus 2015. Nuorten osuus väestöstä uhkaa yhä pienentyä. Haettu 3.9.2018 osoitteesta: https:/www.stat.fi/til/vaenn/2015/ vaenn_2015_2015-10-30_tie_001_fi.html

Tilastokeskus 2016. Elinajanodote. Haettu 3.9.2018 osoitteesta: www.stat.fi/org/tilastokeskus/elinajanodote.html

Tilastokeskus 2017. Tapaturma- ja väkivaltakuolemat vähentyneet viidenneksellä kymmenessä vuodessa. Haettu 5.9.2018 osoitteesta: http://www. stat.fi/ti1/ksyyt/2016/ksyyt_2016_2017-12-29_ tie_001_fi.html 